\title{
Networking agrobiodiversity management to foster biodiversity-based agriculture. A review
}

\author{
Vanesse Labeyrie ${ }^{1,2}$ (1) Martine Antona ${ }^{1,2} \cdot$ Jacques Baudry $^{3} \cdot$ Didier Bazile $^{1,2} \cdot$ Örjan Bodin $^{4} \cdot$ Sophie Caillon $^{5} \cdot$ \\ Christian Leclerc $^{6,7}$. Christophe Le Page ${ }^{1,2}$. Sélim Louafi ${ }^{6,7}$ • Juliette Mariel ${ }^{1,2}$. François Massol ${ }^{8,9}$. \\ Mathieu Thomas ${ }^{6,7}$
}

Accepted: 30 November 2020 / Published online: 7 January 2021

(C) INRAE and Springer-Verlag France SAS, part of Springer Nature 2021

\begin{abstract}
Biodiversity-based agriculture is the main form of agriculture practiced by smallholder farmers, who produce half the world's food, especially in the Global South. This form of agriculture relies on planned biodiversity intentionally managed by farmers and on the associated biodiversity that spontaneously colonizes the agroecosystem. In recent decades, there have been increasing calls from researchers and society to support biodiversity-based agriculture as an alternative paradigm to today's industrial agriculture. Building adapted governance and management systems for enhancing farmers' access to agrobiodiversity is a key challenge for the development of biodiversity-based agriculture. To achieve this, a better understanding of how farmer's access agrobiodiversity is needed, and in particular, how this access is affected by interactions between farmers and with institutions, i.e., social networks. In this article, we first review the literature on the role of social networks in farmers' access to agrobiodiversity, in the form of crop diversity and associated biodiversity, and the related knowledge to manage this diversity. This review points at a major knowledge gap concerning how the composition and structure of these networks affect farmers' access to agrobiodiversity. Then, we review literature on social-ecological networks to identify how this framework developed for environmental management could contribute in getting a better understanding of the role of social networks' structure and composition in farmers' access to agrobiodiversity. Based on this review, we propose a social-ecological network framework dedicated to crop diversity. Finally, we present potential applications of this framework to develop new participatory approaches for agrobiodiversity management and governance, adapted to biodiversity-based agriculture.
\end{abstract}

Keywords Agrobiodiversity · Agroecology · Social networks · Social-ecological interactions · Participatory approaches · Management/governance

Vanesse Labeyrie

vanesse.labeyrie@cirad.fr

CIRAD, UPR GREEN, F-34398 Montpellier, France

GREEN, University of Montpellier, CIRAD, Montpellier, France

INRAE, UMR 980, BAGAP, Rennes, France

4 Stockholm University, Stockholm Resilience Centre, 10691 Stockholm, Sweden

5 CEFE, University Montpellier, CNRS, EPHE, IRD, Universite Paul Valéry Montpellier 3, Montpellier, France
6 CIRAD, UMR AGAP, F-34398 Montpellier, France

7 AGAP, University of Montpellier, CIRAD, INRAE, Institut Agro, Montpellier, France

8 Université de Lille, CNRS, UMR 8198 - Evo-Eco-Paleo, SPICI group, Lille, France

9 Univ. Lille, CNRS, Inserm, CHU Lille, Institut Pasteur de Lille, U1019 - UMR 9017 - CIIL - Center for Infection and Immunity of Lille, F-59000 Lille, France 


\section{Contents}

1. Introduction

2. Social networks and farms' access to agrobiodiversity

2.1. Knowledge circulation networks and social learning

2.2. Collaboration networks and access to associated biodiversity

2.3. Seed circulation networks and access to crop diversity

3. Linking the structure and outcomes of agrobiodiversity management networks: A social-ecological framework

3.1. Insights from social-ecological networks research on crop diversity access

3.2. A social-ecological network framework for crop diversity management

4. Conclusion and perspectives

Acknowledgements

Data availability

Compliance with ethical standards

References

\section{Introduction}

Biodiversity-based farming is the main form of agriculture practiced by smallholder farmers, who represent about $85 \%$ of all farms in the world (Lowder et al. 2016) and produce an estimated $50 \%$ of the food calories at the global scale (Ricciardi et al. 2018). A fast-growing literature provides evidence for the role of biodiversity in supporting ecosystem services provision in agroecosystems and in enhancing their resilience (Dainese et al. 2019; Renard and Tilman 2019; Roux et al. 2009). It pleads also for supporting biodiversitybased agriculture as an alternative development paradigm (Frison 2016; Tscharntke et al. 2012). This form of agriculture relies on the management of agrobiodiversity, broadly defined as "the diversity of living organisms that contribute to food and agriculture" (Qualset et al. 1995). It includes three components: $(i)$ planned agrobiodiversity, i.e., organisms that are intentionally implanted and tended in farmlands, (ii) associated agrobiodiversity, i.e., organisms that spontaneously colonize the agroecosystem, such as pollinators or pest predators, and (iii) the diversity of associated knowledge systems (Jackson et al. 2012). Supporting biodiversity-based agriculture is a core challenge, as recent studies suggest that agroecosystems' homogenization increases their vulnerability to climatic, biotic, or economic variability (e.g., Renard and Tilman 2019). Such a homogenization from the plot to the landscape scale thus jeopardizes the resilience of agricultural and food systems in the face of global changes.

Facilitating farmers' access to agrobiodiversity is key to support biodiversity-based agriculture (Almekinders and Louwaars 2002). This cannot be achieved without developing collaborative and pluralistic governance approaches (Leventon et al. 2017; Halewood et al. 2013), grounded in local socioeconomic dynamics, and without recognizing the diversity of values, rules, and practices related to the use and circulation of agrobiodiversity (Jackson et al. 2007). In the past, policies and regulatory frameworks were rather designed to promote highly standardized cropping systems (monocultures) and agricultural landscapes in order to access world competitive markets. The implementation of these policies raised major concerns among civil society organizations and researchers. Both argued that such regulatory frameworks lead to the disempowerment of small farmers and to their impoverishment because they reduce the availability and increase restrictions on farms' access to the biological and cognitive resources required for low-input agriculture.

Farmers play a key role in maintaining, generating and circulating agrobiodiversity, together with a wide range of stakeholders, e.g., governmental and non-governmental organizations, the private sector, and international and regional institutions (McGuire and Sperling 2016; Hauck et al. 2016). However, little is known about how this diversity of stakeholders and the way they interact together determine the availability of a large pool of agrobiodiversity at the landscape level, and affect the ability of individual farmers to access this pool (Fig. 1). This gap calls for new research on how the social relational networks involving these different stakeholders favor or limit farms' access to agrobiodiversity.

A substantial literature shows that the structure and composition of social networks play a crucial role in driving the management and governance outcomes for a wide range of natural resources (Barnes et al. 2016; Bodin and Crona 2009). Applying such social networks framework to the field of agrobiodiversity could help develop innovative governance systems for enhancing farmer's access to agrobiodiversity, based on the empowerment of local stakeholders and the collaboration across and within institutional levels (Folke et al. 2005).

The study of social networks involved in agrobiodiversity management expanded over the last decade, with a main focus on crop diversity (Calvet-Mir and Salpeteur 2016; Coomes et al. 2015; Thomas et al. 2011; Pautasso et al. 2013), while a small number of studies were dedicated to associated diversity (e.g., Hauck et al. 2016), and knowledge (e.g., Isaac 2012). This literature encompasses scattered case studies using different methods, which hampers the formulation of general conclusions. In turn, this lack of knowledge hinders the development of adapted governance systems to support biodiversity-based agriculture. We argue that this could be enhanced in two ways.

First, there is a need to formalize a conceptual framework for improving the general understanding on how the structure and composition of the social networks linking the stakeholders involved in agrobiodiversity management affect the access of farms to this resource. We propose in this paper to fill this gap by identifying how the social-ecological network framework developed in the field of environmental 


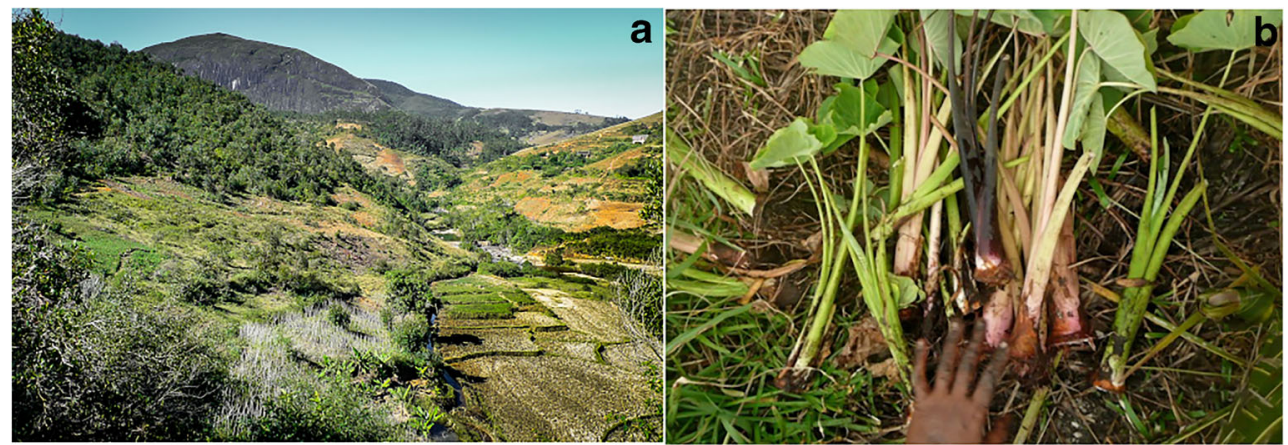

Fig. 1 a Heterogeneous agricultural landscape on the margins of tropical forests in the southern Highlands, region of the Andringitra massif, Ambohimahamasina, Madagascar (@ Stéphanie Carrière, 2012). The diversified agricultural landscapes shaped by smallholder farmers, such as those observed in this region of Madagascar, are home to a rich associated biodiversity that includes insectivorous birds, bats, or pollinators; b Exchange of cuttings of a diversity of taro (Colocasia esculenta) landraces between women farmers in Wakatr tribe, Ouvea,

management (Bodin 2017) could be applied to the three components of agrobiodiversity (e.g., crop biodiversity, associated diversity and knowledge). We then lay the foundations of a conceptual framework dedicated to crop biodiversity, as the previous social-ecological network framework built for common-pool natural resources could not be applied. Such a framework would especially be instrumental in guiding the implementation of large-scale cross-sectional surveys or simulation studies, required for building generic knowledge.

Second, there is a need to apply the results of this research to develop innovative agrobiodiversity management and governance mechanisms adapted to biodiversity-based agriculture through participatory approaches. Integrating these results in participatory modeling would especially allow to explore how different patterns of interactions between stakeholders affect farms' access to agrobiodiversity. This could help in designing more effective ways of collective and institutional organization for agrobiodiversity management and governance. For instance, this approach could contribute in designing modes of organizations for community-based agrobiodiversity management initiatives, such as community seed banks (Vernooy et al. 2015), experience-sharing networks (Rosset et al. 2011), or landscape approaches (Vialatte et al. 2019).

This paper further details these two gaps, and contributes in addressing them. The first section reviews the literature that explores the role of social networks in farmers' access to agrobiodiversity. The second section proposes a network-centered framework for investigating this relationship, focusing on crop diversity for which existing social-ecological network frameworks do not apply. Last, the third section raises perspectives on applications of social network analysis to participatory modeling approaches aiming at building innovative agrobiodiversity management and governance mechanisms. This paper focuses on diversified agriculture, which is particularly prevalent in the Global South, but we believe that its
New Caledonia. (@) Vanesse Labeyrie, 2010). Crop diversity is one component of agrobiodiversity playing a key role in smallholder agriculture. Farmers' access to this diversity is strongly conditioned by their social network. For instance, in New Caledonia, one single farmer can grow dozens of taro landraces she has obtained from a variety of sources, mostly from other farmers, but also from market or extension services

conclusions are also relevant for the transition of low-diversity agriculture.

\section{Social networks and farms' access to agrobiodiversity}

The majority of smallholder farmers in the global south practice agriculture based on the management of agrobiodiversity at different scales, from the plot to the landscape, or even across landscapes (Altieri et al. 2012). Growing a diversity of crop species and varieties is a widespread strategy in small-scale agriculture, and farmers' varieties are genetically diverse (Jarvis et al. 2008). Furthermore, smallholder farmers frequently diversify their land uses, combining different annual, perennial or agroforestry cropping systems in the same landscape, and including natural and semi-natural areas such as hedgerows, fallows, pastures, and forests (Tscharntke et al. 2012). An abundant literature highlights the importance of biodiversity at the population, community, and landscape levels for the food security of small farms (Thrupp 2000; Waha et al. 2018), for dietary diversity (Remans et al. 2014), and for the balance between income and food production (Anderman et al. 2014). Ecological studies further stress the effect of biodiversity on the productivity of agroecosystems at different scales in the long term, and on its stability in the face of socioeconomic and biological or climatic perturbations (Clough et al. 2011; Lin 2011; Renard and Tilman 2019). Beyond productivity, biodiversity drives agroecosystem capacity to deliver a variety of ecosystem services (DeClerck et al. 2016; Hatt et al. 2018) and stabilizes the provision of these services over time (Isbell et al. 2017; Mijatović et al. 2013). Diversification of crop and of land uses in particular has been shown to increase associated diversity, including that of beneficial organisms such as pollinators or pest predators, 
thereby enhancing biological regulation (Burel et al. 2013; Garbach et al. 2017).

Such a biological diversity exists thanks to a diversity of practices, and associated knowledge (Jackson et al. 2012; Leclerc and Coppens d'Eeckenbrugge 2012). The diversity of knowledge systems related to agrobiodiversity is thus pivotal in biodiversity-based agriculture (Altieri 2004). Indeed, beyond the diversity of biological resources, the way they are protected, chosen, multiplied, cultivated, or bred largely drives the capacity of agroecosystems to provide contributions to human populations in space and over time. These knowledge systems cover a variety of domains including agronomic management (e.g., soil adaptation; Bazile et al. 2008, or synergies and competition between species; Isaac et al. 2018), the processing and use of products, but also symbolic or relational aspects (Jackson et al. 2012). A key aspect of agrobiodiversity management is its holistic and integrative dimension, i.e., how farmers carefully evaluate trade-offs among its different contributions, some positive, some negative (Ango et al. 2014), and also incorporate the complexity of their norms and values. Incentives for agrobiodiversity management rarely account for the diversity of local worldviews including social, spiritual, and symbolic dimensions, while they affect a variety of domains of agrobiodiversity management including the spatial organization of crops in farmers' fields and in the landscape (Bonnemaison 1996), their selection beyond a purely utilitarian motivation (Caillon and Lanouguère-Bruneau 2005), and their circulation answering to social norms (Thomas and Caillon 2016).

Diversified agroecosystems are hence complex entities involving coupled ecological and social interactions (Lescourret et al. 2015). They span different spatial scales, from the plot to the landscape scale, as well as different time scales, and involve multiple institutional levels (Jackson et al. 2010). These systems have emergent properties and unpredictable behavior, as short-term management actions at the plot scale can have unexpected consequences for agroecosystem dynamics at larger spatial and temporal scales, and vice versa. Collaboration and resource exchange are pivotal to sustain such systems in which the stakeholders are strongly ecologically interdependent despite having divergent values and objectives, and where knowledge is fragmented (Armitage et al. 2009). Fostering biodiversity-based agriculture hence relies to a great extent on the capacity of stakeholders to exchange resources, learn, and collaborate across institutional levels, as well as across spatial and social units (Duru et al. 2015a; Jackson et al. 2007).

Farmers' access to material and immaterial resources, including agrobiodiversity, is largely influenced by their network of social relationships with different stakeholders (e.g., Bandiera and Rasul 2006). These networks are qualified as "informal" in the literature because they are largely selforganized and emerge without the support of official institutions (Coomes et al. 2015). They involve a variety of individual stakeholders and primarily farmers, as well as organizational stakeholders such as private actors, NGOs and extension services, or other rural development actors (McGuire and Sperling 2016; Isaac 2012; Hauck et al. 2016). Knowledge concerning these networks considerably progressed thanks to the research field commonly denoted as social network analysis (SNA; Wasserman and Faust 1994). This field has undergone major development in the social sciences since the 1990s, and has been applied in a diversity of fields such as environmental management (Bodin 2017) and rural development (Rockenbauch and Sakdapolrak 2017) over the last decade. SNA is dedicated to analyze the structure of interactions between stakeholders, represented in the form of networks (Fig. 2). Theoretical frameworks and empirical and simulation studies were especially developed to understand how social networks structure relates to different kinds of outcomes, such as material or immaterial resources circulation, or collaboration success.

An increasing number of studies argue that supporting networking between farmers as well as with a diversity of other stakeholders would enhance farmers' access to a diversified pool of knowledge (Duru et al. 2015b), to associated agrobiodiversity (Hauck et al. 2016; Salliou and Barnaud 2017) and to crop diversity (Almekinders and Louwaars 2002). Furthermore, studies building on social network theory indicate that social networks shape the circulation of knowledge and crop, and also indirectly that of associated organisms, hence playing on farm's access to agrobiodiversity in two ways: First, by driving the maintenance, generation or decrease of agrobiodiversity at the landscape level, hence contributing in determining the pool of agrobiodiversity available for farmers at this level (e.g., Pautasso et al. 2013). Second, by determining the capacity of individual farmers to access this global pool of agrobiodiversity (e.g., Kawa et al. 2013). In the following section, we summarize the role of social networks in farms' access to the three components of agrobiodiversity, i.e., knowledge, associated diversity, and crop diversity. For each component, we review the literature exploring how the structure and composition of social networks relate to farms' access to agrobiodiversity.

\subsection{Knowledge circulation networks and social learning}

Social learning is a key mechanism for agrobiodiversity management because of the complex and unpredictable nature of the ecological processes involved. Facilitating social learning requires developing networks of stakeholders with different knowledge systems and worldviews to create a cooperative decision-making environment in which trust, understanding, and mutual reliance develop over time (Stubbs and Lemon 2001). Social learning allows individuals to develop an 


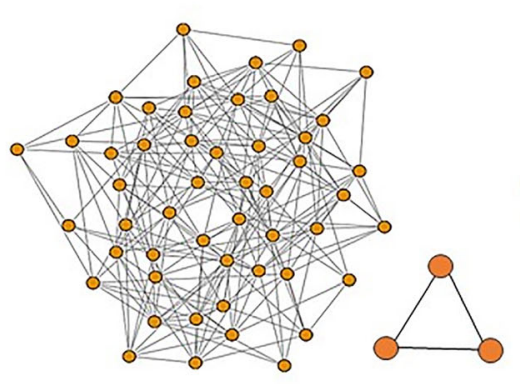

a

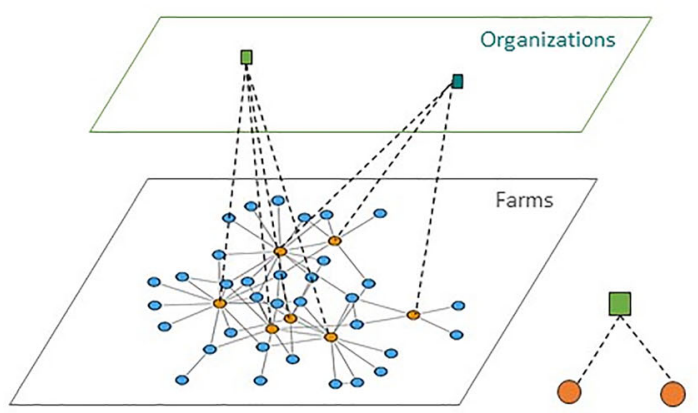

d

Fig. 2 Representation of different structural patterns of social networks. Nodes represent the social actors that can be of different kinds: individuals (e.g., farmers) or organizations. Ties represent their interactions that can be of different kinds as well (e.g., collaboration, flows of material, or immaterial resources). Top: Simple networks (e.g., farmer-to farmer network): a Distributed cohesive network. The density of ties is high in this kind of network, where closed triangles are common building blocks. Centralization is low, meaning that there is little variation in the number of connections established by actors (degree) and network configuration is quite different from a star. Modularity is low, meaning that the network is not structured in subgroups. b Centralized network. In this kind of network, centralization is high (star-like network), meaning that a small number of actors have a very high number of connections (orange nodes) while the majority of them have few (blue nodes). Open triangles are common building blocks. The density and modularity are moderate to low. c Modular network. This kind of network structured in subgroups (orange, blue and green) arises through the preferential

understanding that is less individualistic and takes place in wider social units or communities of practice (Reed et al. 2010). In most rural societies that practice biodiversity-based agriculture, practical and theoretical knowledge related to agrobiodiversity management is built in a dynamic way through learning-by-doing and social learning originating from multiple sources (Altieri 2004).

Fostering social learning entails not only collaboration among farmers and other local stakeholder within and between communities, but also communication with institutional stakeholders at different levels of governance (e.g., local, regional, national, and international), and from different sectors (e.g., agriculture, forest, the environment). Indeed, social learning relies on the involvement of stakeholders with a variety of knowledge systems, experiences, and perspectives concerning agrobiodiversity management in its multiple

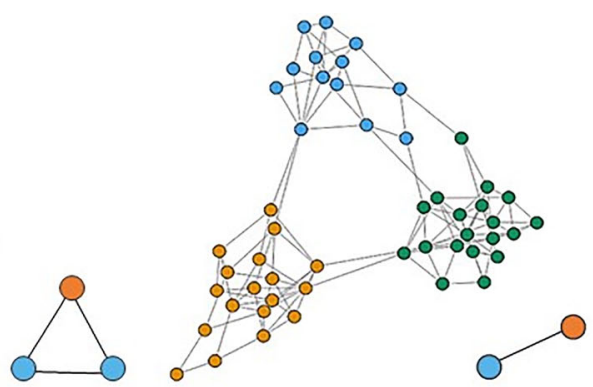

C

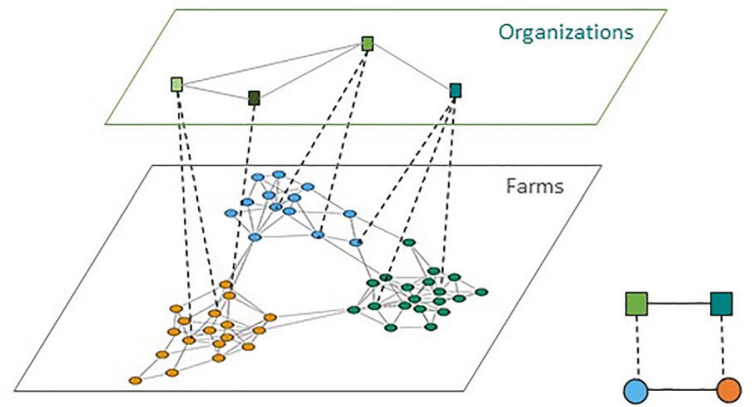

e

interaction of actors presenting the same characteristics (e.g., geographic location, ethnicity, gender). The building block is hence the interaction between two actors presenting the same characteristics. Centralization is low and modularity is high. Bottom: Multilevel networks (e.g., network representing both interactions among farms, and between farms and institutional actors). $\mathbf{d}$ Institutionally centralized network. The network of interactions between levels presents a high centralization as a small number of institutional actors (square and green nodes) interact with farms (round and blue or orange nodes). The density within each layer is low as actors have limited interactions with their peers. Centralization is high in the farm layer as institutions usually rely on a few nodal farms for disseminating advice and planting material. e Polycentric institutional network: several institutions (square nodes) having interactions are connected to farms that act as brokers in their respective communities (orange, blue, green). The centralization of the network of interactions between levels is low. The density of interactions within each layer is higher than in (d), and the centralization is lower

dimensions, including functional, symbolic, or relational aspects. Social learning can be supported by actions such as collective experimentation (Humphries et al. 2015), peer-topeer exchanges (Rosset et al. 2011), farm visits, and workshops involving farmers, and other stakeholders such as extension agents and researchers, to build and share knowledge on biological resources, associated agricultural techniques and practices, and landscape management.

The role of knowledge circulation networks structure in stakeholder access to knowledge diversity and social learning has been widely studied in environmental management (Bodin 2017) and rural development (Conley and Udry 2001) using SNA approaches. However, these frameworks have rarely been applied to agrobiodiversity management. The few studies conducted on this topic indicate that farmers connected to a wider range of stakeholders, especially to 
different rural development organizations (Fig. 2e), tend to learn new practices and diversify their crops at both the plot (e.g., Isaac 2012) and landscape levels (Isaac and Matous 2017). This is in line with previous conceptual and empirical works on social learning networks, which indicate that enhancing social learning requires a balance between "bridging ties" connecting stakeholders or groups (Fig. 2c) with different knowledge and worldviews, and "bounding ties" within groups of stakeholders sharing similar knowledge (DavidsonHunt 2006). Further application of existing frameworks (Berkes 2009) opens promising perspectives to improve our understanding of how social network composition and structure impacts farmers' access to a diversified pool of knowledge related to agrobiodiversity.

\subsection{Collaboration networks and access to associated biodiversity}

Associated agrobiodiversity includes a variety of organisms that play a key role in ecosystem services including pollination, pest regulation, and soil fertility (Dainese et al. 2019). The enhancement of associated biodiversity in agricultural landscapes requires changing individual farming practices in the common interest, especially by limiting the use of pesticides and fertilizers. It also requires coordinating land use practices at the landscape scale (Lichtenberg et al. 2017), with some non-intuitive considerations such as, e.g., the decrease of weed richness in crop fields with increasing weed diversity in neighboring flower strips (Cordeau et al. 2012). A considerable body of literature indicates that enhancing landscape heterogeneity by maintaining natural or semi-natural vegetation in agricultural landscapes and a diversity of cropping systems is instrumental in boosting associated biodiversity (Burel et al. 2013). Increasing the heterogeneity of landscape mosaics requires acting on its composition, but also on its organization, i.e., the spatial arrangement of patches (Fahrig et al. 2011).

Enhancing farms' access to associated agrobiodiversity is hence primarily a matter of collaboration to manage agricultural landscapes for enhancing ecological connectivity. However, although collaborative landscape management has great promise for enhancing ecosystem service delivery in agroecosystems, it has rarely been implemented up to now (Landis 2017). This lack of collaboration between stakeholders at territorial and landscape level often appears as a bottleneck in the development of agroecological farming. One reason for the lack of collaborative landscape management initiatives with the objective of enhancing associated agrobiodiversity is that it raises major collaboration problems as it involves a diversity of stakeholders at different institutional levels with competing interests and divergent views. Furthermore, coordination involves delegation and devolution of power and authority, which is far from easy to accomplish
(Morrison et al. 2019). Collaborative landscape management for associated biodiversity enhancement also raises social learning issues because of the complexity and large spatial and temporal extent of the social-ecological processes involved (Salliou and Barnaud 2017).

The importance of social networks composition and structure in fostering collaboration for landscape management has been widely studied in environmental management and governance (Guerrero et al. 2015), but rarely applied to associated agrobiodiversity management (Hauck et al. 2016). This literature particularly emphasizes the importance of good alignment between social and ecological connectivity, i.e., the existence of social ties between the stakeholders who manage ecologically-linked landscape units (Bodin and Tengö 2012; Guerrero et al. 2013). Studies in this field further show that network cohesiveness (Fig. 2a) is instrumental in building trust, which is a precondition for stakeholders to shift their practices in the common interest and also to limit freeriding. Application of existing social-ecological network frameworks for landscape management opens promising perspectives for enhancing associated biodiversity at the landscape scale (Hauck et al. 2016), hence favoring farms' access to this resource.

\subsection{Seed circulation networks and access to crop diversity}

Accessing a wide range of crop species and varieties is the main production lever for small farms with limited access to inputs (Altieri et al. 2012). Farms' access to crop diversity governs their capacity to implement sustainable forms of agriculture based on ecosystem services (Gevers et al. 2019), as well as their resilience in the face of social and environmental perturbations (McGuire and Sperling 2013; Mwongera et al. 2014). Farms access to crop diversity encompasses two dimensions (Sperling et al. 2008). First, it is conditioned by the amount of diversity available at the landscape level and its distribution, i.e., the variation in the composition of crop portfolios between farms. Studies in different regions of the world converge to show that the diversity of crop species and farmers' varieties at the landscape level, also called gamma diversity in ecology, is systematically larger than the diversity cultivated at the individual farm level, or alpha diversity (e.g., Jarvis et al. 2008). This is due to the high heterogeneity or variation in the composition of crop portfolios between farms, i.e., beta diversity. Second, farms' access to crop diversity is also conditioned by their capacity to get additional crops out of this pool. Social networks are pivotal in both dimensions of farms' access to crop diversity as they drive the maintenance, generation, and diffusion of crop diversity through seed multiplication, selection, conservation, and circulation (Bellon 2004).

Self-organized crop seed circulation networks involving primarily farmers and other stakeholders such as local seed 
sellers, but also private seed distributors, extension services, and NGOs play a key role in this process (Coulibaly et al. 2014). Research on crop circulation networks has expanded over the last decade (Pautasso et al. 2013; Calvet-Mir and Salpeteur 2016) building on SNA theoretical background and methods. The use of SNA is far more developed for crop diversity study than for the other components of agrobiodiversity, but the effect of the structure of crop circulation networks on farms' access to crop diversity was rarely explored. The studies found in the literature focused on different levels of crop diversity: (i) the assemblages (or "portfolio") of crop species grown by farmers (e.g., Abizaid et al. 2016), (ii) the portfolio of farmers' varieties of a given species (e.g., Kawa et al. 2013), or (iii) the genetic composition of crop populations (e.g., Thomas et al. 2015). These studies used different methodological approaches and metrics for describing the structure of crop circulation networks and crop diversity. They described how crops circulate at different temporal scales, ranging from seeds that circulated in the previous growing season to all the circulation events that occur over a farmer's lifetime. Last, they focused on different scales, i.e., the individual or the farm scale, and the landscape scale.

At the farm scale, a small number of case studies explored how farmers' connectivity patterns when exchanging seeds relate to their crop diversity. They dominantly used regression models to test how farmers' centrality in the seed circulation network relates to the diversity of crops they grow, measured using richness or other diversity indexes. Different centrality metrics were used to measure farmers' centrality, the most frequent one being in-degree centrality, i.e., the number of entering connections. These studies found different results concerning this relationship. Some studies such as that of Calvet-Mir et al. (2012) in homegardens in the Spanish Pyrenes found a positive correlation between the number of crop species cultivated by farms and their number of entering connections. In other cases, such a relationship was not validated, for instance in the Amazon for crop species in homegardens (Abizaid et al. 2016) and for cassava farmers' varieties (Kawa et al. 2013), where the most central farmers were not the ones with the more diverse portfolios.

At the landscape scale, some studies provided insights on how the global composition and structure of the seed circulation networks affects crop diversity level and patterns. Most empirical studies at this scale discuss qualitatively this relationship, describing network and crop diversity patterns separately and then discussing how they relate to each other. Even though these studies do not test quantitatively this relationship, they bring valuable insights on how the network structure relates to the availability of crop diversity at the landscape scale and pave the way for future research. For instance, in Kenya, Labeyrie et al. (2016) showed that seed flows were more frequent between farmers belonging to the same ethnolinguistic group (i.e., homophily), and suggested this may explain the partition of farmers' sorghum varieties according to these groups. They further argue that such a structure of seed circulation could be in favor of a higher level of crop diversity at the collective level than expected if ties were established randomly, as limited exchanges between ethnolinguistic groups are expected to impede the uniformization of their crop portfolios and to contribute in maintaining specific varieties in each group (Fig. 2c). At the genetic level, Thomas et al. (2012) reveals that the structure of the seed circulation network of a historical bread wheat variety that circulated among French farmers during the twentieth century matches with the genetic composition of the variety sampled throughout the network. The same author also reported on the impact of a centralized seed network, organized around a "core farmer" (Fig. 2b), on crop genetic diversity (Thomas et al. 2015). By tracing a mixture of bread wheat developed and diffused by this farmer to dozens of others, it showed that the same amount of genetic diversity was maintained in the network of farmers growing this mixture as in the original farm, although a significant differentiation was detected among these versions. This study illustrates how collectives - even organized according to a centralized network - can simultaneously conserve genetic diversity collectively and adapt it to local conditions after a seed flow event.

Last, some simulation studies also bring insights on the linkages between the global structure of seed circulation networks and crop diversity patterns. The study of Barbillon et al. (2015) especially shows that network density, centralization, and modularity (Fig. 2a-c) are key factors driving the circulation and the persistence of crops in a system when applying the same dynamic model of extinction/colonization to networks with different structural properties. Barbillon et al. study indicates that different network structures have different implications for agrobiodiversity conservation depending on the frequency of crop extinction at the farm level. Their results indicate that centralized networks are more efficient in maintaining crop when extinction is frequent, while modular or distributed cohesive networks are more efficient in other cases. These empirical and simulation studies open up promising perspectives for understanding how the overall structure and composition of the crop circulation networks drive the availability of a pool of crop diversity and its accessibility to farmers.

\section{Linking network structure to farm's access to agrobiodiversity: a framework for crop diversity}

The literature review in the previous section showed that social networks play a key role in driving farms' access to the three components of agrobiodiversity, i.e., knowledge, 
associated diversity, and crop diversity. However, how the composition and structure of social networks relate to agrobiodiversity access remains poorly understood. A promising way to advance our understanding of this relationship would be to integrate the valuable insights provided by the literature on social-ecological networks. This research field emerged about fifteen years ago (Janssen et al. 2006), and developed conceptual frameworks to explore the reliance of environmental management outcomes on the kind of stakeholders involved, their relationships, and the way their interactions with one another and with the natural resources are framed (Bodin 2017). Research on social-ecological networks brought major advances on representing the complexity of interactions between human societies and their environment, and deciphering the processes driving the sustainability of social-ecological systems (Bodin et al. 2016). By jointly considering ecological and social interactions, some structural properties of SEN enhancing management efficiency and strengthening the sustainability and resilience of socialecological systems in the face of perturbations have been identified (Barnes et al. 2017). The importance of stakeholders' interactions patterns at the local level has been highlighted in particular, along with their "vertical" interactions with institutional stakeholders (Cohen et al. 2012; Sayles and Baggio 2017).

Existing social-ecological network frameworks can be adapted and applied to analyze the processes driving farms' access to two out of the three agrobiodiversity components, i.e., collaboration for the management of associated diversity and social learning. However, it is not the case for crop diversity, which presents specificities and for which a dedicated framework is needed to guide future research and allow comparing results. Indeed, existing frameworks mainly focus on common-pool or open access resources, which present characteristics and management issues different from those of crop diversity. They were designed to understand how the structure of social-ecological interaction patterns affects the collaboration and social learning for limiting the depletion of natural resources, which is a different objective than that of enhancing agrobiodiversity.

In the case of crop diversity, a first specificity is that the overall level of diversity available at the collective level does not only depend on the capacity of stakeholders to collaborate for a sustainable use of the resource through the modification of their individual practices, but also on their capacity to organize the exchange of crop between them. Hence, for crop diversity, collaboration does not solely intervene in the regulation and coordination of individual practices, but also in the circulation of planting material. Furthermore, unlike the resources usually studied in social-ecological network literature (e.g., fish, water, natural vegetation), the availability of a diverse pool of crops at the collective level does not only require enhancing the biological connectivity, i.e., seed flows, between farms. It rather depends on a compromise: intense crop circulation between farms leads to the uniformization of cultivated plants, while low connectivity can lead to the extinction or inbreeding of crop populations. Last, previous social-ecological network frameworks did not address the issue of individual's resources access as they mostly focus on the availability and dynamic of the resource at the community level, while this issue is pivotal for crop diversity. In this section, we identify potential contributions from the socialecological network literature to the study of network characteristics affecting farms' access to crop diversity, and we propose a dedicated framework.

\subsection{Insights from social-ecological networks research on crop diversity access}

A first insight from the literature on social-ecological networks for agrobiodiversity management is its substantial conceptual background on the social network structures of importance for environmental management. This literature especially emphasizes the importance of the diversity of stakeholders involved in resource management and highlights the importance of connectivity patterns: (i) between farms belonging to different communities or groups, and (ii) between farms and organizations such as NGOs, extension services, or other private actors (Fig. 2d, e). Indeed, most social network studies on crop diversity management focus on connectivity patterns within rural communities (e.g., Abizaid et al. 2016; CalvetMir et al. 2012). They rarely examine the connectivity between communities (e.g., Abizaid et al. 2018; Isaac et al. 2014) and with organizations or institutions (Isaac 2012), while these "bridging" ties are considered to be key in environmental management (Ernstson et al. 2010; Rathwell and Peterson 2012) and in rural development (Krishna 2003).

Second, another interesting insight from social-ecological network research is the possibility of incorporating ecological ties in representations of the networks involved in crop circulation. Indeed, our literature review showed that research on crop diversity management has mostly focused on social connectivity between farms. Little attention has been paid to representing the ecological relationships between farms' crop portfolios, mainly through gene flows, which we believe is an important gap in research on crop circulation networks. Representing both farms and crop portfolios in the form of interconnected "social-ecological" networks would allow the simultaneous analysis of social-, ecological-, and integrated social-ecological relationships. We believe that developing this social-ecological representation of crop diversity management would pave the way for a better understanding of the structure-outcome relationship, as suggested by Bohan et al. (2013) more generally for agroecosystems. In the following section, we thus propose a social-ecological framework for representing how the social and social-ecological interaction 
patterns affect farm's access to crop diversity. Our framework will help address the management "dilemma," i.e., help identify the social-ecological network configurations that create the necessary conditions for a good balance between the maintenance and generation of crop diversity at the landscape level, and its accessibility to farmers.

\subsection{A social-ecological network framework for crop diversity management}

Adhering to the social-ecological network representation (Fig. 3), crop circulation networks consist of social nodes that represent either individual farmers or organizations, and ecological nodes that represent the portfolios of farmers' varieties for each crop species cultivated in the farms. Farmers' varieties being here defined as the basic unit identified and named by farmers at the infraspecific level for management (Berg 2009). Two kinds of social nodes can be distinguished: farms, characterized by their social, economic, biophysical attributes, and organizations or institutional stakeholders who diffuse crop seeds. Ties between social nodes represent different kinds of social relationships they can mobilize to access or exchange seed, including economic relationships. Social ties are directed, reflecting that depending on the nature of the relationship, seed flows can be unidirectional or reciprocated. Lastly, ecological ties reveal nonhuman-mediated gene flows between crop portfolios, which can result for instance from pollen flows between neighboring fields managed by different farmers.

Based on the literature reviewed (section 2.3), we expect the structure of social-ecological networks to play at two levels on farms' access to crop diversity, defined as their ability to get additional crops out of the global pool available at the landscape level. First, the structure and composition of the global network is expected to determine beta diversity, i.e., the heterogeneity in crop portfolio composition at the landscape scale. This is further supported by theoretical models of community ecology, with processes comparable to those of seed circulation, indicating that different network topologies between ecological patches have different impacts on alpha and beta diversities (Economo and Keitt 2008). Second, the position of each farm in the network is expected to determine its capacity to access this additional pool of diversity available at the landscape level, a finding also reminiscent of similar conclusions in community ecology (Economo and Keitt 2010). Hence, different structures of these social-ecological networks would result in different outcomes for farms' access to crop diversity. Below, we build on the literature reviewed in
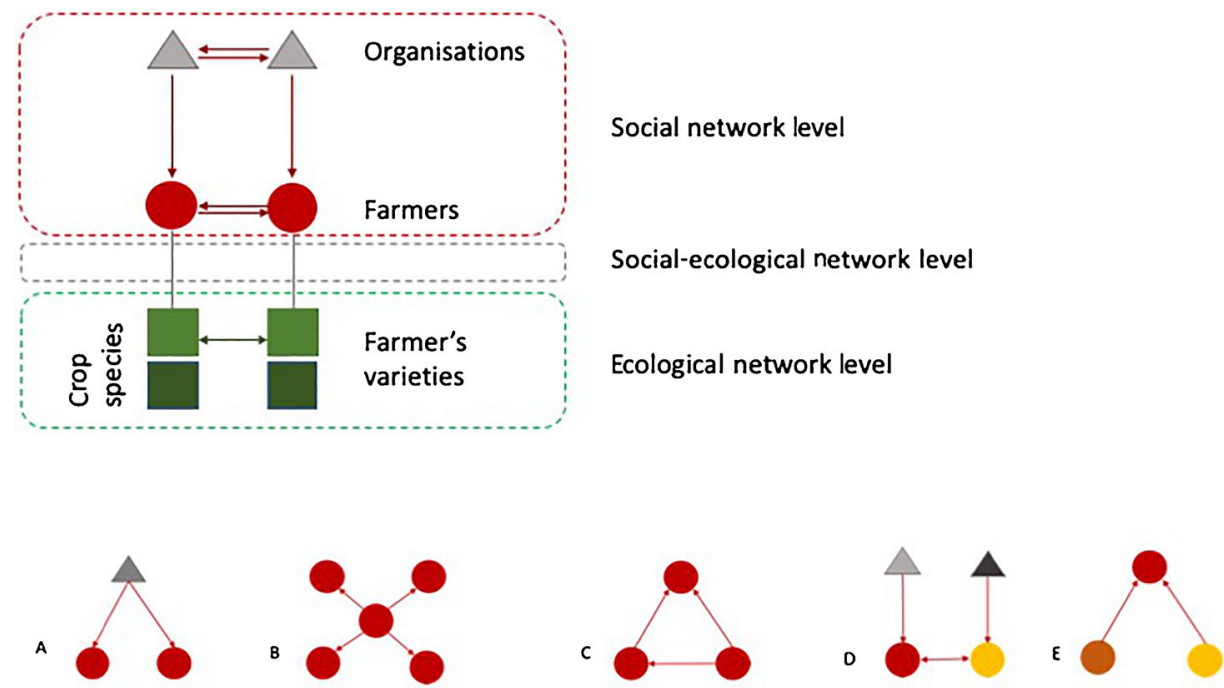

Social patterns

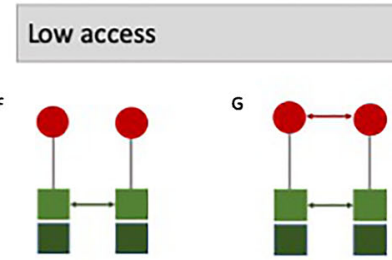

High access

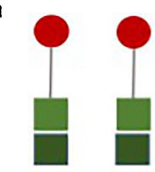

Fig. 3 Social-ecological network representation of interactions involved in farm's access to crop diversity (Top), and local network patterns expected to affect farms' access to crop diversity (Bottom). Nodes represent (i) the portfolios of farmers' variety for the different crop species grown in farms (green squares, the different shades of green represent different species), (ii) farmers (red circles), and (iii)

organizations (triangles) involved in crop diffusion. Edges represent the ecological (i.e., gene flows, green), social (red), and social-ecological (gray) interactions. For social ties, arrows indicate the direction of interactions, stemming from the "source" or "donor" of seed to the "target" or "recipient" 
the previous sections to identify network patterns (Fig. 3, bottom) expected to affect farms' access to crop diversity.

The way the social interactions are framed between farmers as well as with other stakeholders is expected to strongly determine the beta diversity, i.e., the variation in crop portfolio composition at the landscape level, and its accessibility for farmers. Network centralization, i.e., the fact that a small number of farmers (Fig. 3b) or organizations (Fig. 3a) are diffusing seeds to the rest of the farmers, is expected to lead to the uniformization of crops between farms. Hence, the additional diversity of crops available at the collective level is expected to be limited as compared to that grown individually by farms. Furthermore, centralization may result in inequality of access to this resource by farmers (Ricciardi 2015), as some of them may not be connected to the core seed distributors. Centralized networks are thus expected to decrease farms' access to crop diversity.

Conversely, the involvement of a variety of institutional stakeholders (Fig. 3d) in crop management networks, or that of farms presenting different characteristics (Fig. 3e), e.g., socio-cultural, economic, agroecological, is hypothesized to enhance the heterogeneity in crop diversity distribution at the landscape level. Indeed, this diversity of stakeholders is a source of diversity for crops, grown in different conditions and according to different criteria. Environmental research has shown that cross-scale brokers connecting, for example, local, regional, and national management levels are keys to innovation and to the introduction of new resources (Cohen et al. 2012; Hamilton et al. 2020), but their role has rarely been investigated in crop diversity management (Isaac 2012). Furthermore, social-ecological network literature also highlights the role of brokers who connect different communities, i.e., groups of stakeholders closely connected together while loosely connected to other groups, in the introduction and diffusion of new resources (Barnes et al. 2016; Bodin and Norberg 2005; Granovetter 1973). Such processes have been rarely explored in crop diversity studies, but some studies already suggest such brokers play a key role in the introduction of new crops and practices, hence enhancing the diversity available at the collective level (e.g., Valente 1996; Isaac et al. 2014).

Last, social-ecological network literature provides multiple illustrations of the key role of cohesion in social networks (Fig. 3c-also often called closure) in the diffusion of resources within communities (Ernstson et al. 2008; Olsson et al. 2004). Cohesion is expected to enhance farmers' access to crop diversity, but it can lead to the uniformization of crop species and varieties between farms over time. In highly cohesive networks, the additional diversity of crops available at the collective level, i.e., the average beta diversity between a single farm and the rest of the network, may hence be limited as compared to that grown in one farm (i.e., the average alpha diversity). Hence, finding the right balance between cohesion within communities, and connectivity with other communities and institutional stakeholders, is expected to be crucial for enhancing access to crop diversity for farmers.

Social-ecological interaction patterns are also expected to drive farms' access to crop diversity. In the case where farms grow ecologically connected crop portfolios (Fig. 3f, g), the beta diversity is expected to be low because gene flows lead to the uniformization of crops between them. Beta diversity will be even lower when farmers are socially connected (Fig. 3g) and have higher chances to exchange seed. Last, when farms grow crop portfolios ecologically isolated from one another (Fig. 3h, i), the beta diversity at the landscape level is expected to be high, because differences between farms' crop portfolios will be maintained, and even enhanced through local adaptation over time. However, if farms are not socially connected, this beta diversity at the landscape level cannot be exploited and accessed by farmers because of the absence of social connectivity between them (Fig. 3h). On the contrary, if farms are socially connected, then this pool will be accessible for farmers (Fig. 3i).

Beyond these social-ecological connectivity patterns, crop reproductive biology, crop environment, and cultivation practices also impact beta diversity. Crops present differences in their reproductive biology, some being rather allogamous (i.e., dominantly outbreeding), others being rather autogamous (i.e., dominantly self-breeding), or clonally propagated. These differences have strong impacts on the intensity of gene flows and crossing between crop varieties, which can accelerate the uniformization of crops at the infra specific level and thus decrease beta diversity. Then, local adaptive processes, especially adaptation to local soils, climate, biotic environment, and cultivation practices can enhance the differentiation of crops between farms, and increase beta diversity. Such a local adaptation process can even lead to the differentiation of crops cultivated in different conditions despite seed flows between farms (Pressoir and Berthaud 2004; Thomas et al. 2015).

\section{Conclusion and perspectives}

In this article, we have detailed the key role played by social networks involving multiple stakeholders in farms' access to agrobiodiversity, including knowledge, associated diversity of beneficial organisms, and crop diversity. We reviewed studies investigating the relationship between the structure of social networks affecting agrobiodiversity circulation and their outcomes, i.e., the different dimensions of agrobiodiversity access. This review reveals a major gap of knowledge concerning this relationship, as it was never explored beyond local case studies and rare simulation studies. In response to this lack of operational knowledge of general scope, this article identifies the contribution that social-ecological network frameworks could bring, and lays the foundations of a socialecological network framework dedicated to crop diversity 
access as previous frameworks developed for environmental management are not appropriate to deal with its specificities. This framework is expected to contribute in guiding the implementation of future research aiming at building generic knowledge, based on large-scale cross-sectional surveys or simulation studies.

Obtaining more insights into how social networks impact farms' access to crop diversity has major implications for agricultural policies and development programs that usually opt for centralizing the dissemination of biological resources and associated knowledge and with little consideration for existing social organizations (Bocci and Chable 2009; Gevers et al. 2019). This governance option is at risk as centralized management limits farmers' capacity to rapidly respond to social and ecological transformations and to cope with uncertainty (Armitage et al. 2009). New management and governance options should thus be developed to support biodiversitybased agriculture that would rely on collaboration between the different stakeholders involved, grounded on local farmer networks (Coolsaet 2015). However, in order to have more impact on public policies, farmers also need to be more connected with stakeholders across institutional levels.

An increasing number of papers call for a shift from the currently prevailing top-down vision of agricultural support through the diffusion of innovations from research and development to the co-construction of sustainability trajectories by including local knowledge, practices, and collective organizations (Berthet et al. 2016; Duru et al. 2015b; Klerkx et al. 2010). Operational approaches supporting the collaborative management of agrobiodiversity remain rare, with some examples related to participatory plant breeding (Chable et al. 2014; Ceccarelli and Grando 2020), or to collective landscape management for associated biodiversity enhancement (e.g., Steingröver et al. 2010). In most cases, these processes are poorly supported at the institutional level, whether for crop diversity (Berthet et al. 2020) or associated biodiversity (Leventon et al. 2017). Furthermore, these initiatives face multiple obstacles to collaboration, among which power imbalance is a major issue (Porcuna-Ferrer et al. 2020). This calls for the development of participatory approaches that enhance the ability of stakeholder groups to set common objectives and collectively explore a diversity of solutions.

The development of such participatory approaches encompasses three key dimensions. The first is enhancing social learning to enable stakeholders to become aware of their interdependence concerning the different components of agrobiodiversity, and to understand the complex interactions that drive the availability of agrobiodiversity at the collective level and its accessibility to farmers (Bazile 2006). The complexity of interactions hampers their ability to grasp the collective dimension of agrobiodiversity management, which, in turn, limits their willingness to collaborate. Enhancing social learning requires dedicated methods and interactive tools to enable dialog between the knowledge systems of the different stakeholders: scientific, technicians, and farmers. The second dimension is developing dedicated tools to explore scenarios and to discuss the consequences of different network structures on the availability and accessibility of agrobiodiversity to farmers (Chable et al. 2020; Abrami et al. 2008). The third dimension is building trust among stakeholders to encourage the collective definition of desirable outcomes and to nurture their willingness to get involved in a genuine collaborative management of agrobiodiversity (Demeulenaere et al. 2017; Padmanabhan 2008).

Designing and using simulation models with stakeholders can support such transformative change processes by providing a boundary object or negotiating artifact that allows participants to deliberate through a multi-interpretable, consistent, transparent, and verifiable representation of reality (van Bruggen et al. 2019). In their review of methods for studying seed exchange networks in relation to agrobiodiversity, Pautasso et al. (2013) considered both participatory approaches and simulation models as standalone methods located at the opposite corners of a two-dimensional space defined by a qualitative/quantitative axis and an empirical/theoretical axis. In fact, the advantages of combining the two types of methods were already demonstrated several years previously (Voinov and Bousquet 2010). In socioecological science, agent-based simulation models (ABMs) have become the preferred tool as they can represent stakeholders of a given socioecosystem as decision-making entities interacting in a multilevel spatially-explicit virtual environment (Lippe et al. 2019). Used in a participatory way, as promoted by companion modeling, among other approaches (Barreteau et al. 2014), the stakeholders represented as agents in the model react when viewing the simulation. To stimulate interactions among them, participants can be invited to act out their own role in stylized situations created by the organizers in roleplaying sessions (Bousquet et al. 2002).

In Thailand, such participatory simulation workshops with stakeholders involved in the seed system in Ubon Ratchathani Province were organized to collectively explore how the structure and functioning of the provincial seed system affect the dynamics of local rice agrobiodiversity, with the aim of promoting a more balanced partnership between the stakeholders of the system (Abrami et al. 2008). In Mali, a similar approach was used to analyze the functioning of the farmer seed system, and enhanced collective learning for crop diversity management (Bazile and Abrami 2008). The use of social-ecological network analysis and modeling in participatory approaches have a strong potential for exploring with stakeholders how the way their interactions are framed affect their access to agrobiodiversity. Such participatory modeling approaches hence open promising perspectives for developing agrobiodiversity management and governance options that are better adapted to biodiversity-based agriculture. 
Acknowledgments The authors gratefully acknowledge the researchers in the MIRES network, funded by INRAE, and the GDR ReSoDiv, funded by the CNRS, for rich discussions that significantly contributed to this paper. Special thanks to Pierre Barbillon and Saint-Clair ChabertLiddell for their help with the figures, and to Camille Noûs for her meaningful insights. We also thank two anonymous reviewers for their constructive suggestions that significantly improved this paper.

\section{Compliance with ethical standards}

Funding The coordination of this work was aided by training facilities provided by CIRAD which associated senior and junior researchers.

Conflict of interest The authors declare that they have no conflicts of interest.

Authors' contribution Conceptualization, V.L, J.B, M.A, C.L.P; Literature search, V.L, J.M, C.L.P; Writing -Original Draft, V.L, C.L.P; Writing -Review \& Editing, M.A. D.B, Ö.B, S.C, C.L, S.L, J.M, F.M, M.T; Funding Acquisition, V.L.

Ethical approval Not applicable (review).

Data availability Not applicable.

\section{References}

Abizaid C, Coomes OT, Perrault-Archambault M (2016) Seed sharing in Amazonian indigenous rain forest communities: a social network analysis in three Achuar villages. Peru Hum Ecol 44(5):577-594

Abizaid C, Coomes OT, Takasaki Y, Arroyo-Mora JP (2018) Rural social networks along Amazonian Rivers: seeds, labor and soccer among communities on the Napo River. Peru Geogr Rev 108(1):92-119

Abrami G, Bazile D, Trébuil G, Le Page C, Bousquet F, Dionnet M, Vejpas C (2008) Accompagner l'évolution des systèmes semenciers céréaliers au Mali et en Thaillande. Cah Agric 17(2):210-215

Almekinders CJ, Louwaars NP (2002) The importance of the farmers' seed systems in a functional national seed sector. J New Seeds 4(12): $15-33$

Altieri MA (2004) Linking ecologists and traditional farmers in the search for sustainable agriculture. Front Ecol Environ 2(1):35-42

Altieri MA, Funes-Monzote FR, Petersen P (2012) Agroecologically efficient agricultural systems for smallholder farmers: contributions to food sovereignty. Agron Sustain Dev 32(1):1-14

Anderman TL, Remans R, Wood SA, DeRosa K, DeFries RS (2014) Synergies and tradeoffs between cash crop production and food security: a case study in rural Ghana. Food Secur 6(4):541-554

Ango TG, Börjeson L, Senbeta F, Hylander K (2014) Balancing ecosystem services and disservices: smallholder farmers' use and management of forest and trees in an agricultural landscape in southwestern Ethiopia. Ecol Soc 19(1):30. https://doi.org/10.5751/ES-06279-190130

Armitage DR, Plummer R, Berkes F, Arthur RI, Charles AT, DavidsonHunt IJ, Diduck AP, Doubleday NC, Johnson DS, Marschke M (2009) Adaptive co-management for social-ecological complexity. Front Ecol Environ 7(2):95-102

Bandiera O, Rasul I (2006) Social networks and technology adoption in northern Mozambique. Econ J 116(514):869-902. https://doi.org/ 10.1111/j.1468-0297.2006.01115.x

Barbillon P, Thomas M, Goldringer I, Hospital F, Robin S (2015) Network impact on persistence in a finite population dynamic diffusion model: application to an emergent seed exchange network. J Theor Biol 365(1):365-376
Barnes ML, Lynham J, Kalberg K, Leung P (2016) Social networks and environmental outcomes. Proc Natl Acad Sci 113(23):6466-6471

Barnes M, Bodin Ö, Guerrero A, McAllister R, Alexander S, Robins G (2017) The social structural foundations of adaptation and transformation in social-ecological systems. Ecol Soc 22(4):16. https://doi. org/10.5751/ES-09769-220416

Barreteau O, Bousquet F, Etienne $\mathrm{M}$, Souchère V, d'Aquino $\mathrm{P}$ (2014) Companion modelling: a method of adaptive and participatory research. In: Companion modelling: a participatory approach to support sustainable development. Springer, Dordrecht

Bazile D (2006) State-farmer partnerships for seed diversity in Mali. IIED, Londres

Bazile D, Abrami G (2008) Des modèles pour analyser ensemble les dynamiques variétales du sorgho dans un village malien. Cah Agric 17(2):203-209

Bazile D, Dembélé S, Soumaré M, Dembélé D (2008) Utilisation de la diversité variétale du sorgho pour valoriser la diversité des sols au Mali. Cah Agric 17(2):86-94

Bellon M (2004) Conceptualizing interventions to support on-farm genetic resource conservation. World Dev 32(1):159-172. https://doi. org/10.1016/j.worlddev.2003.04.007

Berg T (2009) Landraces and folk varieties: a conceptual reappraisal of terminology. Euphytica 166(3):423-430

Berkes F (2009) Evolution of co-management: role of knowledge generation, bridging organizations and social learning. J Environ Manag 90(5):1692-1702

Berthet ET, Barnaud C, Girard N, Labatut J, Martin G (2016) How to foster agroecological innovations? A comparison of participatory design methods. J Environ Plan Manag 59(2):280-301

Berthet ET, Bosshardt S, Malicet-Chebbah L, van Frank G, Weil B, Segrestin B, Rivière P, Bernard L, Baritaux E, Goldringer I (2020) Designing innovative management for cultivated biodiversity: lessons from a pioneering collaboration between French farmers, facilitators and researchers around participatory bread wheat breeding. Sustainability 12(2):605

Bocci R, Chable V (2009) Peasant seeds in Europe: stakes and prospects. J Agric Environ Int Dev 103(1-2):81-93

Bodin Ö (2017) Collaborative environmental governance: achieving collective action in social-ecological systems. Science 357:eaan1115

Bodin Ö, Crona BI (2009) The role of social networks in natural resource governance: what relational patterns make a difference? Glob Environ Chang 19(3):366-374

Bodin Ö, Norberg J (2005) Information network topologies for enhanced local adaptive management. Environ Manag 35(2):175-193

Bodin Ö, Tengö M (2012) Disentangling intangible social-ecological systems. Glob Environ Chang 22(2):430-439

Bodin Ö, Robins G, Mcallister RRJ, Guerrero AM, Crona B, Tengö M, Lubell M (2016) Theorizing benefits and constraints in collaborative environmental governance: a transdisciplinary social-ecological network approach for empirical investigations. Ecol Soc 21(1):40

Bohan DA, Raybould A, Mulder C et al (2013) Networking agroecology: integrating the diversity of agroecosystem interactions. Adv Ecol Res 49(1): 1-67

Bonnemaison J (1996) Gens de pirogue et gens de la terre. Editions de l'ORSTOM, Paris

Bousquet F, Barreteau O, D'Aquino P, Etienne M, Boissau S, Aubert S, Le Page C, Babin D, Castella JC (2002) Multi-agent systems and role games: collective learning processes for ecosystem management. In: Complexity and ecosystem management. The theory and practice of multi-agent systems. Edward Elgar Publishing, Cheltenham

Burel F, Aviron S, Baudry J, Le Féon V, Vasseur C (2013) The structure and dynamics of agricultural landscapes as drivers of biodiversity. In: Landscape Ecology for Sustainable Environment and Culture. Springer, Dordrecht 
Caillon S, Lanouguère-Bruneau V (2005) Gestion de l'agrobiodiversité dans un village de Vanua Lava (Vanuatu) : stratégies de sélection et enjeux sociaux. J Société Océan 120-121:129-148. https://doi.org/ $10.4000 /$ jso. 451

Calvet-Mir L, Salpeteur M (2016) Humans, plants, and networks: a critical review. Environ Soc 7(1):107-128. https://doi.org/10.3167/ ares.2016.070107

Calvet-Mir L, Calvet-Mir M, Molina JL, Reves-Garcia V (2012) Seed exchange as an agrobiodiversity conservation mechanism. A case study in Vail Fosca, Catalan Pyrenees, Iberian Peninsula. Ecol Soc 17(1):29. https://doi.org/10.5751/ES-04682-170129

Ceccarelli S, Grando S (2020) Participatory plant breeding: who did it, who does it and where? Exp Agric 56(1):1-11

Chable V, Dawson J, Bocci R, Goldringer I (2014) Seeds for organic agriculture: development of participatory plant breeding and farmers' networks in France. In: Organic farming, prototype for sustainable agricultures. Springer, Dordrecht

Chable V, Nuijten E, Costanzo A, Goldringer I, Bocci R, Oehen B, Rey F, Fasoula D, Feher J, Keskitalo M, Koller B, Omirou M, MendesMoreira P, van Frank G, Naino Jika AK, Thomas M, Rossi A (2020) Embedding cultivated diversity in society for agro-ecological transition. Sustainability 12(3):784

Clough Y, Barkmann J, Juhrbandt J et al (2011) Combining high biodiversity with high yields in tropical agroforests. Proc Natl Acad Sci 108(20):8311-8316

Cohen PJ, Evans LS, Mills M (2012) Social networks supporting governance of coastal ecosystems in Solomon Islands. Conserv Lett 5(5): 376-386

Conley T, Udry C (2001) Social learning through networks: the adoption of new agricultural technologies in Ghana. Am J Agric Econ 83(3): $668-673$

Coolsaet B (2015) Transformative participation in agrobiodiversity governance: making the case for an environmental justice approach. J Agric Environ Ethics 28(6):1089-1104

Coomes OT, McGuire SJ, Garine E, Caillon S, Mckey D, Demeulenaere E, Jarvis D, Aistara G, Barnaud A, Clouvel P (2015) Farmer seed networks make a limited contribution to agriculture? Four common misconceptions. Food Policy 56(1):41-50

Cordeau S, Petit S, Reboud X, Chauvel B (2012) Sown grass strips harbour high weed diversity but decrease weed richness in adjacent crops. Weed Res 52(1):88-97

Coulibaly H, Bazile D, Sidibé A (2014) Modelling seed system networks in Mali to improve farmers seed supply. Sustain Agric Rese 3(4): $18-32$

Dainese M, Martin EA, Aizen MA et al (2019) A global synthesis reveals biodiversity-mediated benefits for crop production. Sci Adv 5(10): eaax 0121

Davidson-Hunt IJ (2006) Adaptive learning networks: developing resource management knowledge through social learning forums. Hum Ecol 34(4):593-614

DeClerck FA, Jones SK, Attwood S, Bossio D, Girvetz E, ChaplinKramer B, Norieg IL (2016) Agricultural ecosystems and their services: the vanguard of sustainability? Curr Opin Environ Sustain 23(1):92-99

Demeulenaere É, Rivière P, Hyacinthe A, Baltassat R, Baltazar S, Gascuel JS, Lacanette J, Montaz H, Pin S, Ranke O (2017) Participatory plant breeding and scale issues. On a collaboration between farmer plant breeders and field geneticists. Nat Sci Soc 25(4):336-346

Duru M, Therond O, Fares M (2015a) Designing agroecological transitions; a review. Agron Sustain Dev 35(4):1237-1257. https://doi. org/10.1007/s13593-015-0318-x

Duru M, Therond O, Martin G, Martin-Clouaire R, Magne MA, Justes E, Journet EP, Aubertot JN, Savary S, Bergez JE (2015b) How to implement biodiversity-based agriculture to enhance ecosystem services: a review. Agron Sustain Dev 35(4):1259-1281. https:// doi.org/10.1007/s13593-015-0306-1

Economo EP, Keitt TH (2008) Species diversity in neutral metacommunities: a network approach. Ecol Lett 11(1):52-62

Economo EP, Keitt TH (2010) Network isolation and local diversity in neutral metacommunities. Oikos 119(1):1355-1363

Ernstson H, Sörlin S, Elmqvist T (2008) Social movements and ecosystem services - the role of social network structure in protecting and managing urban green areas in Stockholm. Ecol Soc 13(2):39

Ernstson H, Barthel S, Andersson E, Borgström ST (2010) Scale-crossing brokers and network governance of urban ecosystem services: the case of Stockholm. Ecol Soc 15(4):28

Fahrig L, Baudry J, Brotons L, Burel FG, Crist TO, Fuller RJ, Sirami C, Siriwardena GM, Martin JL (2011) Functional landscape heterogeneity and animal biodiversity in agricultural landscapes. Ecol Lett 14(2):101-112

Folke C, Hahn T, Olsson P, Norberg J (2005) Adaptive governance of social-ecological systems. Annu Rev Environ Resour 30(1):441 73

Frison EA (2016) From uniformity to diversity: a paradigm shift from industrial agriculture to diversified agroecological systems. IPES, Louvain-la-Neuve

Garbach K, Milder JC, DeClerck FA, Montenegro de Wit M, Driscoll L, Gemmill-Herren B (2017) Examining multi-functionality for crop yield and ecosystem services in five systems of agroecological intensification. Int J Agric Sustain 15(1):11-28

Gevers C, van Rijswick HF, Swart J (2019) Peasant seeds in France: fostering a more resilient agriculture. Sustainability 11(11):3014. https://doi.org/10.3390/su11113014

Granovetter M (1973) The strength of weak ties. Am J Sociol 78(1): $1360-1380$

Guerrero AM, McAllister R, Corcoran J, Wilson KA (2013) Scale mismatches, conservation planning, and the value of social-network analyses. Conserv Biol 27(1):35-44

Guerrero A, Bodin Ö, McAllister R, Wilson K (2015) Achieving socialecological fit through bottom-up collaborative governance: an empirical investigation. Ecol Soc 20(4):41. https://doi.org/10.5751/ES08035-200441

Halewood M, Noriega IL, Louafi S (2013) The global crop commons and access and benefit-sharing laws: examining the limits of international policy support for the collective pooling and management of plant genetic resources. In: Crop genetic resources as a global commons. Routledge, New-York

Hamilton M, Hileman J, Bodin Ö (2020) Evaluating heterogeneous brokerage: new conceptual and methodological approaches and their application to multi-level environmental governance networks. Soc Networks 61(1):1-10

Hatt S, Boeraeve F, Artru S, Dufrêne M, Francis F (2018) Spatial diversification of agroecosystems to enhance biological control and other regulating services: an agroecological perspective. Sci Total Environ 621(1):600-611

Hauck J, Schmidt J, Werner A (2016) Using social network analysis to identify key stakeholders in agricultural biodiversity governance and related land-use decisions at regional and local level. Ecol Soc 21(2):49. https://doi.org/10.5751/ES-08596-210251

Humphries S, Rosas JC, Gómez M, Jiménez J, Sierra F, Gallardo O, Avila C, Barahona M (2015) Synergies at the interface of farmerscientist partnerships: agricultural innovation through participatory research and plant breeding in Honduras. Agric Food Secur 4(1):27. https://doi.org/10.1186/s40066-015-0046-0

Isaac ME (2012) Agricultural information exchange and organizational ties: the effect of network topology on managing agrodiversity. Agric Syst 109:9-15

Isaac ME, Matous P (2017) Social network ties predict land use diversity and land use change: a case study in Ghana. Reg Environ Chang 17(16):1823-1833 
Isaac ME, Anglaaere LC, Akoto DS, Dawoe E (2014) Migrant farmers as information brokers: agroecosystem management in the transition zone of Ghana. Ecol Soc 19(2):56. https://doi.org/10.5751/ES06589-190256

Isaac ME, Cerda R, Rapidel B, Martin AR, Dickinson AK, Sibelet N (2018) Farmer perception and utilization of leaf functional traits in managing agroecosystems. J Appl Ecol 55(1):69-80

Isbell F, Adler PR, Eisenhauer N, Fornara D, Kimmel K, Kremen C, Letourneau DK, Liebman M, Polley HW, Quijas S (2017) Benefits of increasing plant diversity in sustainable agroecosystems. J Ecol 105(4):871-879

Jackson LE, Pascual U, Hodgkin T (2007) Utilizing and conserving agrobiodiversity in agricultural landscapes. Agric Ecosyst Environ 121(3): 196-210

Jackson L, van Noordwijk M, Bengtsson J, Foster W, Lipper L, Pulleman M, Said M, Snaddon J, Vodouhe R (2010) Biodiversity and agricultural sustainagility: from assessment to adaptive management. Curr Opin Environ Sustain 2(1-2):80-87

Jackson LE, Pulleman MM, Brussaard L, Bawa KS, Brown GG, Cardoso IM, de Ruiter PC, García-Barrios L, Hollander AD, Lavelle P, Ouédraogo E, Pascual U, Setty S, Smukler SM, Tscharntke T, van Noordwijk M (2012) Social-ecological and regional adaptation of agrobiodiversity management across a global set of research regions. Glob Environ Chang 22(3):623-639

Janssen MA, Bodin Ö, Anderies JM, Elmqvist T, Ernstson H, Mcallister RRJ, Olsson P, Ryan P (2006) Toward a network perspective of the study of resilience in social-ecological systems. Ecol Soc 11(1):15

Jarvis DI, Brown AHD, Cuong PH, Collado-Panduro L, LatournerieMoreno L, Gyawali S, Tanto T, Sawadogo M, Mar I, Sadiki M, Hue NTN, Arias-Reyes L, Balma D, Bajracharya J, Castillo F, Rijal D, Belqadi L, Rana R, Saidi S, Ouedraogo J, Zangre R, Rhrib K, Chavez JL, Schoen D, Sthapit B, de Santis P, Fadda C, Hodgkin T (2008) A global perspective of the richness and evenness of traditional crop-variety diversity maintained by farming communities. Proc Natl Acad Sci 105(14):5326-5331

Kawa NC, McCarty C, Clement CR (2013) Manioc varietal diversity, social networks, and distribution constraints in rural Amazonia. Curr Anthropol 54(6):764-770

Klerkx L, Aarts N, Leeuwis C (2010) Adaptive management in agricultural innovation systems: the interactions between innovation networks and their environment. Agric Syst 103(1):390-400

Krishna A (2003) Partnerships between local governments and community-based organisations: exploring the scope for synergy. Public Adm Dev 23(4):361-371

Labeyrie V, Thomas M, Muthamia ZK, Leclerc C (2016) Seed exchange networks, ethnicity, and sorghum diversity. Proc Natl Acad Sci 113: 98-106

Landis DA (2017) Designing agricultural landscapes for biodiversitybased ecosystem services. Basic Appl Ecol 18(1):1-12

Leclerc C, Coppens d'Eeckenbrugge G (2012) Social organization of crop genetic diversity. The G x E x S interaction model. Diversity 4(1):1-32

Lescourret F, Magda D, Richard G, Adam-Blondon AF, Bardy M, Baudry J, Doussan J, Dumont B, Lefèvre F, Litrico I (2015) A social-ecological approach to managing multiple agro-ecosystem services. Curr Opin Environ Sustain 14(1):68-75

Leventon J, Schaal T, Velten S, Dänhardt J, Fischer J, Abson DJ, Newig J (2017) Collaboration or fragmentation? Biodiversity management through the common agricultural policy. Land Use Policy 64(1):112

Lichtenberg EM, Kennedy CM, Kremen C, Batáry P, Berendse F, Bommarco R, Bosque-Pérez NA, Carvalheiro LG, Snyder WE, Williams NM, Winfree R, Klatt BK, Åström S, Benjamin F, Brittain C, Chaplin-Kramer R, Clough Y, Danforth B, Diekötter T, Eigenbrode SD, Ekroos J, Elle E, Freitas BM, Fukuda Y, GainesDay HR, Grab H, Gratton C, Holzschuh A, Isaacs R, Isaia M, Jha S,
Jonason D, Jones VP, Klein AM, Krauss J, Letourneau DK, Macfadyen S, Mallinger RE, Martin EA, Martinez E, Memmott J, Morandin L, Neame L, Otieno M, Park MG, Pfiffner L, Pocock MJO, Ponce C, Potts SG, Poveda K, Ramos M, Rosenheim JA, Rundlöf M, Sardiñas H, Saunders ME, Schon NL, Sciligo AR, Sidhu CS, Steffan-Dewenter I, Tscharntke T, Veselý M, Weisser WW, Wilson JK, Crowder DW (2017) A global synthesis of the effects of diversified farming systems on arthropod diversity within fields and across agricultural landscapes. Glob Chang Biol 23(11): 4946-4957

Lin BB (2011) Resilience in agriculture through crop diversification: adaptive management for environmental change. BioScience 61(3):183-193

Lippe M, Bithell M, Gotts N, Natalini D, Barbrook-Johnson P, Giupponi C, Hallier M, Hofstede GJ, Le Page C, Matthews RB, Schlüter M, Smith P, Teglio A, Thellmann K (2019) Using agent-based modelling to simulate social-ecological systems across scales. GeoInformatica 23(2):269-298. https://doi.org/10.1007/s10707018-00337-8

Lowder SK, Skoet J, Raney T (2016) The number, size, and distribution of farms, smallholder farms, and family farms worldwide. World Dev 87(1):16-29

McGuire S, Sperling L (2013) Making seed systems more resilient to stress. Glob Environ Chang 23(3):644-653. https://doi.org/10. 1016/j.gloenvcha.2013.02.001

McGuire S, Sperling L (2016) Seed systems smallholder farmers use. Food Secur 8(1):179-195

Mijatović D, Van Oudenhoven F, Eyzaguirre P, Hodgkin T (2013) The role of agricultural biodiversity in strengthening resilience to climate change: towards an analytical framework. Int J Agric Sustain 11(2): 95-107

Morrison TH, Adger WN, Brown K, Lemos MC, Huitema D, Phelps J, Evans L, Quinn (2019) The black box of power in polycentric environmental governance. Glob Environ Chang 57(1):101934

Mwongera C, Boyard-Micheau J, Baron C, Leclerc C (2014) Social process of adaptation to environmental changes: how Eastern African societies intervene between crops and climate. Weather Clim Soc 6(3):341-356. https://doi.org/10.1175/WCAS-D-13-00034.1

Olsson P, Folke C, Berkes F (2004) Adaptive comanagement for building resilience in social-ecological systems. Environ Manag 34(1):75-91

Padmanabhan MA (2008) Collective action in agrobiodiversity management: gendered rules of reputation, trust and reciprocity in Kerala, India. J Int Dev 20(1):83-97

Pautasso M, Aistara G, Barnaud A, Caillon S, Clouvel P, Coomes OT, Delêtre M, Demeulenaere E, de Santis P, Döring T, Eloy L, Emperaire L, Garine E, Goldringer I, Jarvis D, Joly HI, Leclerc C, Louafi S, Martin P, Massol F, McGuire S, McKey D, Padoch C, Soler C, Thomas M, Tramontini S (2013) Seed exchange networks for agrobiodiversity conservation. A review. Agron Sustain Dev 33(1):151-175. https://doi.org/10.1007/s13593-012-0089-6

Porcuna-Ferrer A, Fiala V, Freyer B, van Etten J, Vernooy R, Probst L (2020) Do community seed banks contribute to the social-ecological resilience of communities? A case-study from Western Guatemala. Int J Agric Sustain 18(3):232-249

Pressoir G, Berthaud J (2004) Population structure and strong divergent selection shape phenotypic diversification in maize landraces. Heredity 92(2):95-101

Qualset CA, McGuire PE, Warburton ML (1995) In California: 'agrobiodiversity' key to agricultural productivity. Calif Agric 49(6):45-49. https://doi.org/10.3733/ca.v049n06p45

Rathwell KJ, Peterson GD (2012) Connecting social networks with ecosystem services for watershed governance: a social ecological network perspective highlights the critical role of bridging organizations. Ecol Soc 17(2):24. https://doi.org/10.5751/ES-04810-170224 
Reed M, Evely AC, Cundill G, Fazey IRA, Glass J, Laing A, Newig J, Parrish B, Prell C, Raymond C (2010) What is social learning? Ecol Soc 15(4):r1

Remans R, Wood SA, Saha N, Anderman TL, DeFries RS (2014) Measuring nutritional diversity of national food supplies. Glob Food Secur 3(3-4): 174-182

Renard D, Tilman D (2019) National food production stabilized by crop diversity. Nature 571(7764):257-260

Ricciardi V (2015) Social seed networks: identifying central farmers for equitable seed access. Agric Syst 139(1):110-121

Ricciardi V, Ramankutty N, Mehrabi Z, Jarvis L, Chookolingo B (2018) How much of the world's food do smallholders produce? Glob Food Secur 17(1):64-72

Rockenbauch T, Sakdapolrak P (2017) Social networks and the resilience of rural communities in the Global South: a critical review and conceptual reflections. Ecol Soc 22(1):10. https://doi.org/10.5751/ ES-09009-220110

Rosset PM, Machín Sosa B, Roque Jaime AM, Ávila Lozano DR (2011) The Campesino-to-Campesino agroecology movement of ANAP in Cuba: social process methodology in the construction of sustainable peasant agriculture and food sovereignty. J Peasant Stud 38(1):161-191

Roux X, Barbault R, Baudry J, Burel F, Doussan I, Garnier E, Herzog F, Lavorel S, Lifran R, Roger-Estrade J, Sarthou J-P, Trommetter M (2009) Agriculture and biodiversity: promoting synergies. INRA, Paris

Salliou N, Barnaud C (2017) Landscape and biodiversity as new resources for agro-ecology? Insights from farmers' perspectives. Ecol Soc 22(2):16. https://doi.org/10.5751/ES-09249-220216

Sayles JS, Baggio JA (2017) Social-ecological network analysis of scale mismatches in estuary watershed restoration. Proc Natl Acad Sci 114(10):E1776-E1785. https://doi.org/10.1073/pnas.1604405114

Sperling L, Cooper HD, Remington T (2008) Moving towards more effective seed aid. J Dev Stud 44(4):586-612

Steingröver EG, Geertsema W, van Wingerden WK (2010) Designing agricultural landscapes for natural pest control: a transdisciplinary approach in the Hoeksche Waard (the Netherlands). Landsc Ecol 25(6):825-838

Stubbs M, Lemon M (2001) Learning to network and networking to learn: facilitating the process of adaptive management in a local response to the UK's national air quality strategy. Environ Manag 27(3):321-334

Thomas M, Caillon S (2016) Effects of farmer social status and plant biocultural value on seed circulation networks in Vanuatu. Ecol Soc 21(2):13. https://doi.org/10.5751/ES-08378-210213
Thomas M, Dawson JC, Goldringer I, Bonneuil C (2011) Seed exchanges, a key to analyze crop diversity dynamics in farmer-led on-farm conservation. Genet Resour Crop Evol 58(3):321-338. https://doi.org/10.1007/s10722-011-9662-0

Thomas M, Demeulenaere E, Dawson JC, Khan AR, Galic N, JouannePin S, Remoue C, Bonneuil C, Goldringer I (2012) On-farm dynamic management of genetic diversity: the impact of seed diffusions and seed saving practices on a population-variety of bread wheat. Evol Appl 5(8):779-795

Thomas M, Thépot S, Galic N, Jouanne-Pin S, Remoué C, Goldringer I (2015) Diversifying mechanisms in the on-farm evolution of crop mixtures. Mol Ecol 24(12):2937-2954

Thrupp LA (2000) Linking agricultural biodiversity and food security: the valuable role of agrobiodiversity for sustainable agriculture. Int Aff 76(2):283-297

Tscharntke T, Clough Y, Wanger TC, Jackson L, Motzke I, Perfecto I, Vandermeer J, Whitbread A (2012) Global food security, biodiversity conservation and the future of agricultural intensification. Biol Conserv 151(1):53-59

Valente TW (1996) Social network thresholds in the diffusion of innovations. Soc Networks 18(1):69-89

van Bruggen A, Nikolic I, Kwakkel J (2019) Modeling with stakeholders for transformative change. Sustainability 11(3):825

Vernooy R, Shrestha P, Sthapit, B. (Eds.). (2015) Community seed banks: origins, evolution and prospects. Routledge, New York

Vialatte A, Barnaud C, Blanco J, Ouin A, Choisis JP, Andrieu E, Sheeren D, Ladet S, Deconchat M, Clément F, Esquerré D, Sirami C (2019) A conceptual framework for the governance of multiple ecosystem services in agricultural landscapes. Landsc Ecol 34(7):1653-1673. https://doi.org/10.1007/s10980-019-00829-4

Voinov A, Bousquet F (2010) Modelling with stakeholders. Environ Model Softw 25(11):1268-1281

Waha K, van Wijk MT, Fritz S, See L, Thornton PK, Wichern J, Herrero M (2018) Agricultural diversification as an important strategy for achieving food security in Africa. Glob Chang Biol 24(8):3390 3400. https://doi.org/10.1111/gcb.14158

Wasserman S, Faust K (1994) Social network analysis: methods and applications. Cambridge university press, Cambridge

Publisher's note Springer Nature remains neutral with regard to jurisdictional claims in published maps and institutional affiliations. 